GRASAS Y ACEITES, 60 (3), SPECIAL ISSUE, 297-307, 2009,

ISSN: 0017-3495

DOI: $10.3989 / g y a .130908$

\title{
Dry cured ham quality as related to lipid quality of raw material and lipid changes during processing: a review
}

\author{
By Gandemer Gilles
}

\author{
Institut National Recherche Agronomique, centre de Lille, \\ 2 Chaussée Brunehaut, Estrées-Mons, BP 50136, 80203 Péronne cedex, France \\ ( ${ }^{*}$ Corresponding author: gilles.gandemer@ mons.inra.fr)
}

\section{RESUMEN}

Relación de la calidad del jamón curado con la calidad de los lípidos de la materia prima y sus cambios durante el proceso: una visión global.

Los lípidos desempeñan un papel fundamental en las características sensoriales de los jamones curados. Tanto la cantidad como la composición de los lípidos de las materias primas afectan a la calidad de los jamones. Las características de los lípidos dependen en gran medida de los sistemas de crianza desarrollados en las diferentes zonas de Europa. Durante el proceso, los lípidos sufren reacciones como la lipolisis y la oxidación. La lipolisis genera ácidos grasos libres a lo largo de todo el proceso, siendo los más abundantes los ácidos grasos poliinsaturados. Los lípidos también están sujetos a la oxidación, la cual genera muchos compuestos volátiles. Estos volátiles afectan al aroma de los jamones curados asociándose a notas tales como la rancidez, carne vieja o curado. De acuerdo con el genotipo y las condiciones de crianza de los cerdos y los parámetros del proceso, los jamones curados tienen un perfil sensorial específico. En este artículo se examinan los conocimientos actuales sobre los lípidos y la calidad del jamón curado.

PALABRAS CLAVE: Calidad sensorial - Jamón curado Lípidos - Lipolisis - Oxidación.

\section{SUMMARY}

Dry cured ham quality as related to lipid quality of raw material and lipid changes during processing: a review.

Lipids play a key role in sensory traits of dry cured hams. Both the quantity and the composition of lipids in raw material affect dry-cured hams quality. The lipid characteristics strongly depend on rearing systems developed in different area in Europe. During processing, lipids undergo lipolysis and oxidation. Phospholipids are the main substrates of both lipolysis and oxidation. Lipolysis forms free fatty acids rich in polyunsaturated fatty acids all along the process. Lipids are also subjected to oxidation which forms many volatile compounds. These volatiles affect in the aroma of dry-cured hams and are associated with aroma notes such as rancid, aged meat or dry-cured. According to the genotype and the rearing conditions of pigs and the parameters of processing, dry-cured hams have specific sensory profiles. This paper reviews the present knowledge on lipids and dry-cured ham quality.

KEY-WORDS: Dry-cured ham - Lipid - Lipolysis Oxidation - Sensory quality.

\section{INTRODUCTION}

Many quality traits of dry cured hams depend on lipids of muscle and adipose tissues of raw material and on their changes during processing (Gandemer, 2002). That is why numerous studies were devoted to lipids in ham both in fresh meat and in ham during processing. Lipids are largely involved in sensory traits of the final dry products. Thus lipids play a key role in aroma of dry-cured hams through both ways: (i) lipids, mainly triacylglycerols (TAG) located in adipose tissues and intermuscular adipose cells, are solvent of many aroma components (ii) lipids, mainly phospholipids located in membrane of muscular cells and, to a lesser extend triacylglycerols, are precursors of many volatiles affecting aroma of hams through a complex set of chemical reactions. Lipids are also strongly correlated with other sensory traits such aspect and texture (Ventanas et al., 2007).

Lipids traits of raw material are strongly related to rearing systems of pigs (Buscailhon and Monin, 1994b; Lopez-Bote, 1998; Coutron-Gamboti et al., 1998). This includes many factors among them breed, feeding system and some physiological parameters such as age at slaughter and physical exercise appear as the main ones. In several areas in Europe, producers have developed specific rearing systems which involve local breeds and extensive feeding systems based on natural feed resources (chestnuts, grass, and acorns) to have raw materials with original traits of composition (Léon-Camacho et al., 2004).

During processing of dry-cured ham, lipids undergo numerous alterations through two main sets of reactions: lipolysis and oxidation (Gandemer, 1999 and 2002). The intensity of these reactions depends on many parameters of the technology including the length of the different periods of processes, the level and the way of salting, the ambient conditions during ripening (Buscailhon and Monin, 1994a; Toldra and Flores, 1998). Many works were devoted to find the optimal conditions of processing between traditional practices and more modern technological options to adapt the products to consumer demands. 
In European countries, mainly in southern ones, a large scale of dry-cured hams with typical traits is available on the market. This diversity is the consequences of alchemies found by the producers between traits of raw material and options selected in the process.

This paper is an overview of the present knowledge on lipids and quality of dry-cured hams, focused on the lipid traits of raw material and the changes in lipids during the processing as related to aroma of final products.

\section{LIPID TRAITS OF MUSCLES AND ADIPOSE TISSUES}

In European countries, most of the dry-cured are manufactured from muscles and adipose tissues from pigs reared in intensive systems. Pigs are from industrial genotypes reared indoors and fed a commercial concentrated diet. These diets mainly consist in cereals and soya meal and contain a low amount of fat (3-4\%). Pigs have a fast growth rate and are slaughtered at 100-120 kg around 5-6 months of age. Selected against fatness since half a century, carcasses of these animals are very lean (Girard, et al., 1988b). Sometimes, pigs are slaughtered heavier (160-180 kg) and older (9-12 months; i.e. Parma area) (Bosi et al., 2000). Muscle and adipose tissues of these pigs show very similar compositional traits. In some limited areas of Europe, pigs are produced in traditional rearing systems: the most famous ones are Iberian and Corsican ones (Benito et al., 2000; Coutron-Gambotti et al., 1999a). These systems rely on local breeds (Iberian, Corsican) reared outdoors and on a feeding strategy based on the availability of natural resources (acorns, grass, roots, oaks). The pigs are slaughtered between 18 and 24 months of age because they have a low growth rate and are subjected to alternating periods of scarcity (summer) and abundance (autumn) (Coutron-Gambotti et al., 1999a; Lopez-Bote, 1998). Pigs are fattened under chestnut grooves or oak plantations eating large quantities of chestnuts or acorns for 4-6 months during the winter. During this period, adipose and muscle tissues acquire their typical chemical traits (Narvaez-Rivas et al., 2008a) which are characterized by a large development of subcutaneous adipose tissue and a sharp increase in intramuscular lipid content leading to raw matter very different from these of industrial pigs (Coutron-Gambotti et al., 1998a; Lopez-Bote, 1998).
Briefly, pigs reared in traditional systems (Iberian, Corsican) are fattier than industrial ones. They have very thick adipose tissues and more intramuscular fat. The formers exhibit backfats with a thickness between 25 and $50 \mathrm{~mm}$ (Benito et al., 2000; Secondi et al., 1992). Their muscles have higher intramuscular lipid content than these of industrial pigs (Table 1). This is mainly the consequence of triacylglycerol (TAG) accumulation while phospholipids $(\mathrm{PL})$ content is very similar in the muscles of both local and industrial genotypes of pigs (Gandemer, 1997). The main cause of the high TAG content in muscles of local genotypes is the fattening period which takes place when pigs are old (16-18 months) and have a low capacity to deposit muscle in carcass. Consequently these pigs deposit a large amount of the feed energy as fat in both adipose tissue and muscles. PL content of muscles is not greatly affected by rearing conditions.

Fatty acid compositions of TAGs from both local and industrial pigs show high proportions of saturated fatty acids (SFA) and monounsaturated fatty acids (MUFA) and low proportion of polyunsaturated fatty acids (PUFA) (Table 2) (Bout et al., 1988a; Tejeda et al., 2001). Numerous rearing factors have been described as factors affecting fatty acid composition (Girard et al., 1988a). However, differences in fatty acid composition are mainly explained by differences in fatness of the carcasses and the muscles (Gandemer et al., 1989). More developed is the backfat or higher is the lipid content of muscles, less is the proportion of PUFA. This is explained by the fact that the excess of fat deposited in adipose and muscle tissues of these pigs come from de novo fatty acid synthesis which provides SFA and MUFA and dilutes PUFA from dietary lipids. Many experiments focused on the relation between fatty acid composition of TAGs and dietary lipids or genotypes demonstrate that these two parameters have a low effect, when animals are compared at the same degree of fatness.

More recently, the attention was focused on TAG composition because TAGs represent the chemical forms in which the fatty acids are in tissues. The main TAGs in pig fat are POO (32-36\%), PSO (19-28\%), POL $(5-8 \%)$ and OOO (4-10\%), PPO (3-4\%) where $\mathrm{P}, \mathrm{S}, \mathrm{O}, \mathrm{L}$ mean palmitic, stearic, oleic and linoleic acids respectively (Table 2). TAG composition is strongly correlated with fatty acid composition. However, differences in TAG composition are more marked than those in fatty acid composition. So TAG

Table 1

Comparative lipid composition of Biceps femoris from dry-cured ham of various European origins (Lipid content are expressed in $\mathrm{g} / 100 \mathrm{~g}$ fresh muscle)

\begin{tabular}{lcccc}
\hline & Bayonne & Serrano & Iberian & Corsican \\
\hline & $\mathrm{N}=40$ & $\mathrm{~N}=6$ & $\mathrm{~N}=10$ & $\mathrm{~N}=6$ \\
Total lipids & $2.6 \pm 0.1$ & $3.5 \pm 0.5$ & $9.3 \pm 2.9$ & $5.3 \pm 1.7$ \\
Triacylglycerols & $2.0 \pm 0.1$ & $2.7 \pm 0.5$ & $8.6 \pm 2.9$ & $4.6 \pm 1.6$ \\
Phospholipids & $0.60 \pm 0.01$ & $0.75 \pm 0.06$ & $0.72 \pm 0.09$ & $0.71 \pm 0.01$ \\
\hline
\end{tabular}


Table 2

Comparative lipid traits of dry-cured hams from various European origins

\begin{tabular}{lccrrr}
\hline & $\begin{array}{c}\text { Bayonne } \\
\mathbf{N}=\mathbf{1 0}\end{array}$ & $\begin{array}{c}\text { Parma } \\
\mathbf{N}=\mathbf{8}\end{array}$ & $\begin{array}{c}\text { Serrano } \\
\mathbf{N}=\mathbf{1 0}\end{array}$ & $\begin{array}{c}\text { Iberian } \\
\mathbf{N}=\mathbf{1 0}\end{array}$ & $\begin{array}{c}\text { Corsican } \\
\mathbf{N}=\mathbf{6}\end{array}$ \\
\hline \multicolumn{7}{c}{ Fatty acids (\%) } & & & \\
\hline Saturated & 36.4 & 36.4 & 33.4 & 32.2 & 34.9 \\
Monounsaturated & 52.9 & 52.5 & 55.6 & 58.7 & 55.4 \\
$18: 2$ n-6 & 9.9 & 10.7 & 10.2 & 8.4 & 8.7 \\
$18: 3$ n-3 & 0.7 & 0.4 & 0.8 & 0.6 & 1.0 \\
Polyunsaturated & 10.7 & 11.1 & 11.0 & 9.0 & 9.7 \\
\hline & Triglycerides (\%) & & & \\
\hline POL & 7.2 & 8.1 & 8.5 & 5.4 & 5.8 \\
OOO & 4.4 & 4.0 & 6.2 & 10.8 & 6.5 \\
POO & 41.6 & 43.0 & 45.8 & 47.8 & 42.9 \\
PPO & 4.5 & 4.6 & 3.4 & 3.3 & 4.6 \\
PSO & 27.5 & 26.0 & 19.9 & 18.9 & 25.6 \\
\hline Solid Fat Content at $20{ }^{\circ} \mathrm{C}(\%)$ & 17.3 & 16.7 & 12.0 & 10.8 & 15.9 \\
\hline
\end{tabular}

$\mathrm{P}=$ palmitic acid, $\mathrm{O}=$ Oleic acid, $\mathrm{S}=$ stearic acid

composition is more efficient for distinguishing hams according to the rearing conditions (Riaublanc et al., 1999; Gandemer et al., 2000; Viera-Alcario et al., 2007 and 2008).

Phospholipids (PLs) contain high PUFA proportions (45-55\%) where $1 / 3$ are long chain PUFA with 4, 5 or 6 double bounds. That explains why PLs are the main substrate of lipid oxidation in muscles (Gandemer, 1999). Differences in fatty acid composition of PLs in muscles are very small whatever the genotypes and the rearing conditions of pigs which suggests that the potential sensitivity of intramuscular lipids to oxidation is very similar whatever the origin of raw meat (Gandemer, 1997).

\section{LIPID CHANGES DURING MEAT PROCESSING}

Typical dry-cured ham process includes these steps: salting, post-salting and ripening-drying. However, the conditions in which each step of the process is managed vary largely according to the area of production and the type of product expected. The main differences within each step are time-temperature cycles and relative humidity. These conditions largely affect the kinetics of meat component degradation during processing (Toldra and Flores, 1998).

\subsection{Lipolysis in adipose tissues and muscles}

Lipolysis is one of the main processes of lipid degradation during dry-cured ham processing (Toldra and Flores, 1998). Lipolysis is governed by a set of specific enzymes: lipases and phospholipases. It forms free fatty acids (FFA) from TAGs in adipose tissue and from both TAGs and PLs in muscles.

TAGs and diacylglycerols are hydrolysed by three lipase systems: lipoprotein lipase (LPL), hormone- sensitive lipase (HSL) and an acid lipase located in the blood vessel, cytosol and lysosomes, respectively (Belfrage et al., 1984). A monoacylglycerol (MG) lipase ends the process hydrolyzing the MGs. The activity of the MG lipase is higher than that of HSL. This explains why MGs do not accumulate in tissues. In both backfat and muscles of dry cured ham, lipases have been described as neutral and basic lipases corresponding probably to HLS and LPL. In addition, muscles present an acid lipase activity which is probably a lysosomal lipase (Motilva et al., 1993a). These lipases have activities that decrease during dry-cured processing but remain active during the whole process (Hernandez et al., 1999; Motilva et al., 1993b). In adipose tissues, HSL remains active over 12 months suggesting this lipase is the main enzyme involved in lipolysis in adipose tissue (Motilva et al., 1993c; Toldra and Flores, 1998). In muscles, the activities of HSL and LPL are high during the first 3-4 months of the process then, decline slowly. Acid lipase has low activity during the entire process (Motilva et al., 1993b). Very little is known about the factors affecting the activity of these enzymes. The activity of these enzymes varies according to the anatomical location of muscles (Flores, et al., 1996; Hernandez et al., 1998). Oxidative muscles have a higher activity of both acid lipase and HSL than glycolytic muscles (Flores et al., 1996). These enzymes have similar activity in light and heavy pigs (110-110 kg versus 160-170 kg) (Toldra et al., 1996).

PLs are hydrolysed by specific enzymes, phospholipases and lysophospholipases. Phospholipases are divided into three main groups. Phospholipases $A 1$ and $A 2$ hydrolyse fatty acids in 1 and 2 of the glycerol backbone of PLs, respectively. Lysophospholipases hydrolyse the remaining fatty acid after phospholipases $A$ action (Waite, 1987). Very little is known on these enzymes and their post-mortem activity in skeletal muscles. A work of Alasnier and Gandemer (2000) showed that phospholipases and lysophospholipases were 
active post-mortem in fresh muscles. The main activities were related to basic phospholipases $A$ and lysophospholipases (maximum activity at $\mathrm{pH}$ 89) which are probably membrane-bound enzymes while acid phospholipase A has a low activity. The activity of lysophospolipases is far higher than that of phospholipases in muscles (Alasnier and Gandemer, 2000). This result is consistent with the low proportion of lysophospholipids found in drycured ham. These enzymes are more active in oxidative muscles than in glycolytic ones (Alasnier and Gandemer, 2000). No data are available on the changes in the activities of these enzymes during dry-cured meat processing. However, the increase in the proportion long chain PUFA in FFA during the first 6 months of dry-cured hams processing strongly suggests that these enzymes remains active for at least 6 months (Buscailhon et al., 1994c).

Free fatty acid (FFA) amount increases during dry-cured hams processing in dry cured hams (Coutron-Gambotti \& Gandemer, 1999; Motilva et al., 1993b). It sharply rises from $1-2 \%$ to $10-12 \%$ of total lipids in 10 months in adipose tissue and to 8$20 \%$ of total lipids in muscle depending on technology parameters and raw material traits (Figure 1) (Buscailhon et al., 1994c; Gandemer et al., 2000; Motilva et al., 1994).

Lipolysis is fast during the first 6 months then slows down towards the end of the process in both adipose tissue and muscles (Narvaez-Rivas et al., 2007 and 2008b). In adipose tissue, lipolysis preferentially affects the TAGs containing linoleic acid such as POL (Coutron-Gambotti and Gandemer, 1999). These results could be explained by the liquid state of this TAG while most of the TAGs of pig adipose tissue are solid at the temperatures at which dry-cured hams are processed (Davenel et al., 1999). In muscle, both TAGs and PLs contribute to FFA. The relative contribution of these lipid classes depends on the TAG content in raw material. In most cases, PLs are the main substrates for lipolysis (Figure 1) (Buscailhon et al., 1994c). This conclusion is supported by the fact that the FFA composition is closer to the fatty acid composition of PLs than to that of TAGs whatever the type of ham (Figure 2) (Gandemer et al., 2000). The hypothesis of a PL origin of FFAs is consistent with the decrease in PL content in muscle during dry-cured ham processing (Buscailhon et al., 1994c).

However, TAGs also provide a significant amount of FFAs (30-50\%) in muscles with very high TAG content such as muscles from Iberian and Corsican pigs (Alasnier et al., 1999; Martin et al., 1999). Lipolysis is not significantly affected by feeding system (Cava et al., 1999). Heavy and light pigs have similar pattern of lipolytic enzymes (Toldra et al., 1996). Among technological parameters, the time/temperature cycles of the different stages of processes are the most important and greatly affect FFA content and lipolytic enzyme activity. The longer is the stage and higher is the temperature, the higher is the FFA content of hams. Other parameters have obtained less attention. The use of frozen raw material instead of refrigerated one and reducing salt content in ham have no effect on lipolysis during dry-cured ham processing (CoutronGambotti, et al., 1999b; Motilva et al., 1994). Muscles with a low initial $\mathrm{pH}(<6.1)$ have a higher FFA content all along the process indicating that a low initial $\mathrm{pH}$ promotes lipolysis (Buscailhon et al., 1994d).

Many authors have postulated that lipolysis promotes lipid oxidation during dry-cured ham processing (Antequera et al., 1992; Buscailhon et al., 1994c; Cava et al., 1999). This assertion must be reconsidered on the basis of recent data that support that the two processes would not be interrelated and moreover, that lipolysis could protect long chain PUFA against oxidation. Thus, the amounts of various volatile compounds arising from lipid oxidation decrease during the last months of processing whilst FFA amounts always increase (Buscailhon 1993; Ruiz et al., 1999) and some parameters promoting lipolysis have no effect on volatiles arising from lipid oxidation or on aroma notes related to oxidation products (Buscailhon et al., 1994e). FFAs contain almost all the long chain PUFA initially esterified in PLs of fresh meat (Buscailhon et al., 1994c; Coutron-Gambotti et al., 1999b). These results strongly suggest that the hydrolysis of PLs during processing protects the long chain PUFAs from oxidation. However, the exact mechanism remains unknown.

\subsection{Lipid oxidation in adipose tissue and muscle}

Lipid oxidation is one of the main causes of deterioration in the quality of meat during storage and processing (Morrissey et al., 1998). However, it does not only contribute to off-flavour but it is also essential to the typical aroma of many meat products (Shahidi, et al., 1986).

The overall mechanism of fatty acid oxidation is a chemical process named autoxidation (Frankel, 1982, 1985). This process affects polyunsaturated fatty acids (PUFA) preferentially. This explains why PLs which contain a large amount of these fatty acids, are the main substrates of lipid oxidation in muscles (Gandemer, 1997; Wilson et al., 1976). Lipid oxidation leads to the formation of numerous volatiles through a very complex set of reaction pathways. Attention has been focused on volatile products because of their impact on aroma. The nature and the relative proportions of compounds in the volatile fraction depend on numerous factors. Among them, fatty acid structure, namely the position of the double bounds, is the most important because it determines the structure of volatiles (Frankel, 1984).

Volatile content of muscle and adipose tissues shows a continuous increase during the first months of processing (Figure 3). However, it tends to 


\section{Serrano}

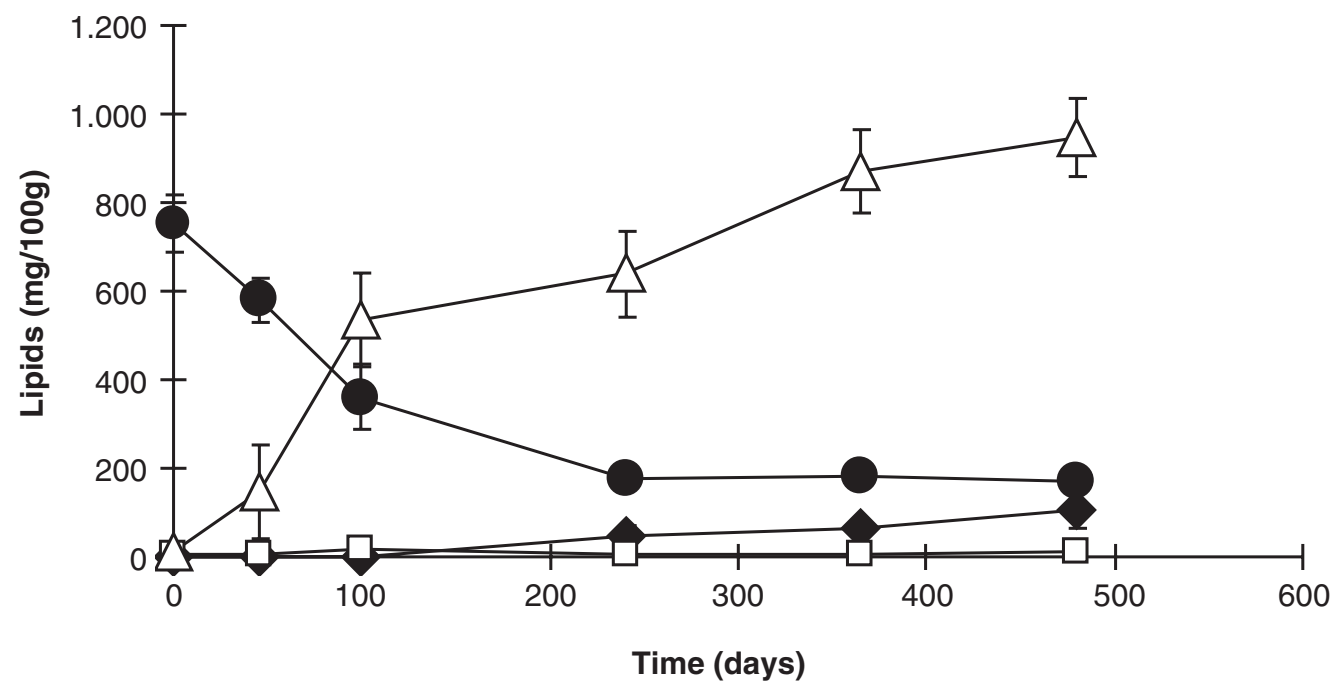

Iberian

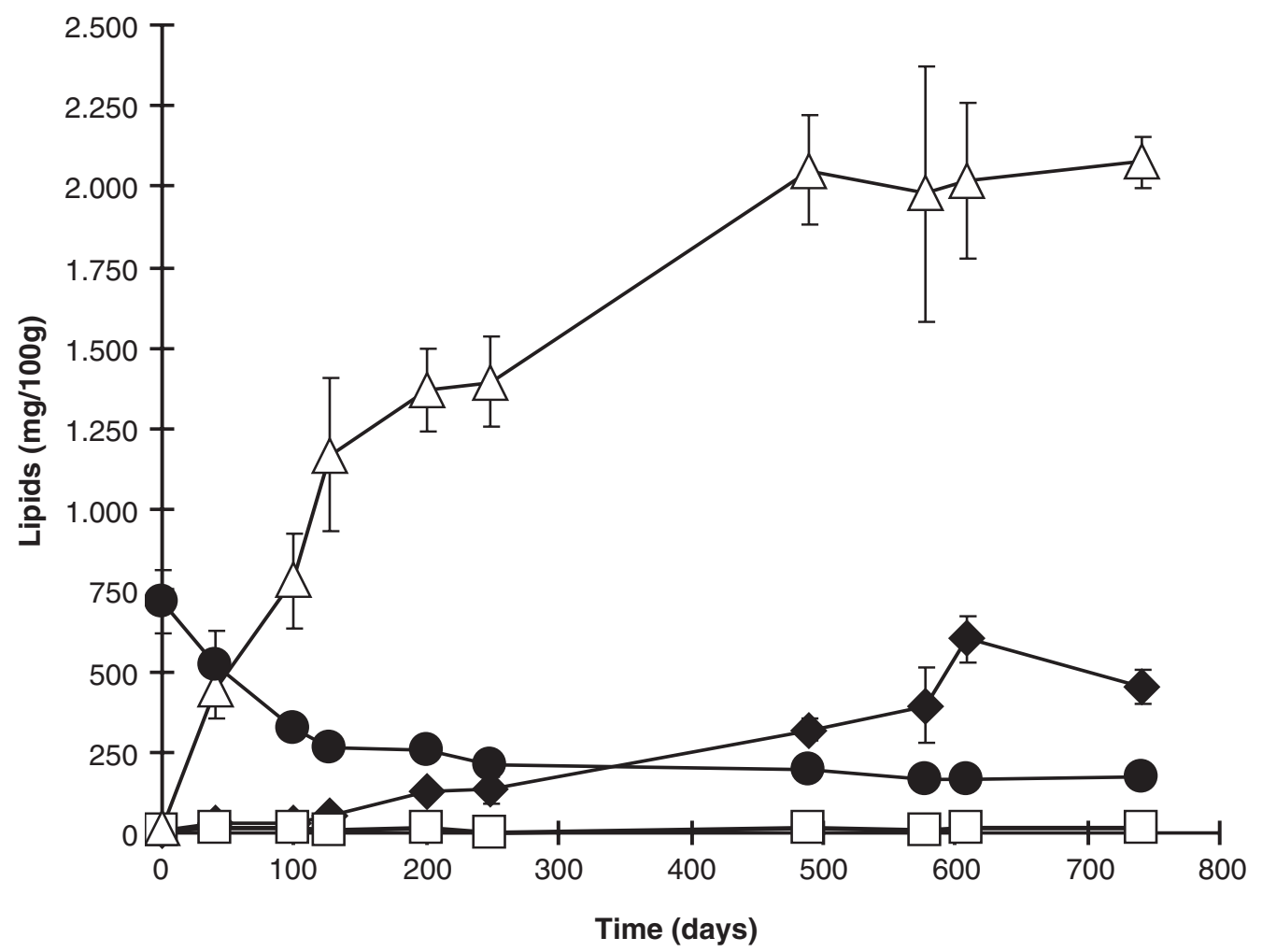

Time (days)

\begin{tabular}{|ll|}
$-\longrightarrow$ Diglycerides & $-\square-$ Monoglycerides \\
$-\triangle$ Free Fatty Acids & - Phospholipids \\
\hline
\end{tabular}

Figure 1

Changes in lipid composition of Serrano and Iberian dry-cured hams during processing.

decrease at the end of the process, mainly in long processes (over 18 months) (Buscailhon et al., 1993; Ruiz et al., 1999). Oxidation leads to a significant decrease in long chain polyunsaturated fatty acids in both FFAs and PLs during dry-cured ham processing (Buscailhon et al., 1994c; CoutronGambotti et al., 1999b). Many factors are involved in the control of lipid oxidation in muscles (Morrissey et al., 1998). High temperatures and long time of drying and ripening favor lipid oxidation (Toldra and Flores, 


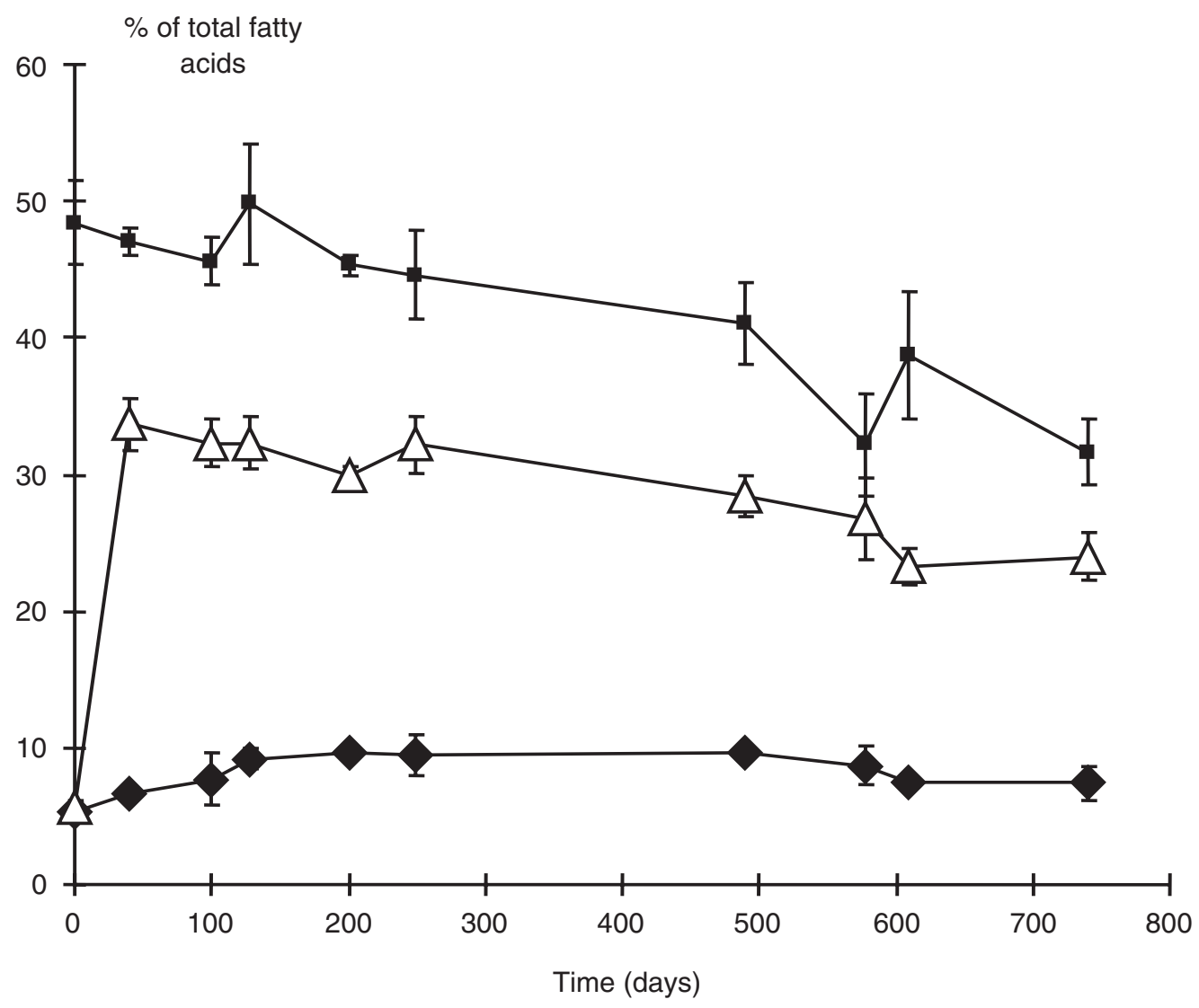

$\longrightarrow$ Triglycerides $\rightarrow-$ Phospholipids $\rightarrow$ Free Fatty Acids

Figure 2

Changes in the proportion of polyunsaturated fatty acids in lipid fractions in Iberian dry-cured ham during processing.

1998). High salt content increases oxidation product content in dry cured hams (Coutron-Gambotti et al., 1999b). In contrast, high vitamin $E$ content in muscles prevents dry-cured hams from oxidation (Cava et al., 1999). A low initial pH in muscles favors lipid oxidation in dry-cured hams (Buscailhon et al., 1994d). The genotype of pigs has a limited effect on lipid oxidation (Berdagué et al., 1993). Volatiles arising from lipid oxidation have been extensively studied in dry cured hams of various countries (French: Berdagué et al., 1993; Italian: Barbieri et al., 1992; Bolzoni et al., 1993; Spanish Serrano and Iberian: Dirinck et al., 1997; Flores et al., 1997; Garcia et al., 1991).

Whatever the type of dry-cured hams, most of the volatiles are formed through lipid oxidation. The main ones are aldehydes. These aldehydes are linear saturated (C5 to C10 alkanals), unsaturated (C5 to C11 alkenals) with some polyunsaturated ones (2,4 nonadienal and decadienal). They have a large impact on the overall aroma of dry cured meat products because of their typical aroma and their low odor threshold (Dirinck et al., 1997; Shahidi et al., 1986). These aldehydes exhibit unpleasant odors such as fatty, oily, rancid, deep fried (nonanal, t-2-heptenal, 2-pentyl-furan, 2,4 decadienal) whereas other volatiles have more pleasant odor notes such as greenish odor (hexanal). Ketones arising from lipid oxidation are mainly methylketones (C5-C10). They exhibit a large variety of aroma notes such as fruity (2-heptanone, 2-decanone, 2undecanone), oily and fatty (2-dodecanone) or blue cheese (2-heptanone) (Shahidi et al., 1986). One of the possible origins of these methyl ketones are an incomplete b-oxidation of free fatty acids by bacteria.

Linear, saturated or unsaturated alcohols (C4C8) contribute to the overall aroma of dry-cured meat products, mainly unsaturated ones such as 1octen-3-ol (mushroom) and 1-penten-3-ol (grass) (Shahidi et al., 1986). In contrast, hydrocarbons have no significant impact on aroma because of their high odor threshold (Dirinck et al., 1997; Shahidi et al., 1986). Whatever the type of drycured products, volatile fractions show a similar set of oxidation products. It is not surprising because the fatty acid compositions of TAGs and PLs which determine the type of volatiles formed during oxidation are similar in all the types of hams (see part 1). So the main differences between dry-cured hams are mainly related to the quantity of volatiles formed during the process (Buscailhon et al., 1993; Dirinck et al., 1997; Garcia et al., 1991). The quantity formed depends on the content of 


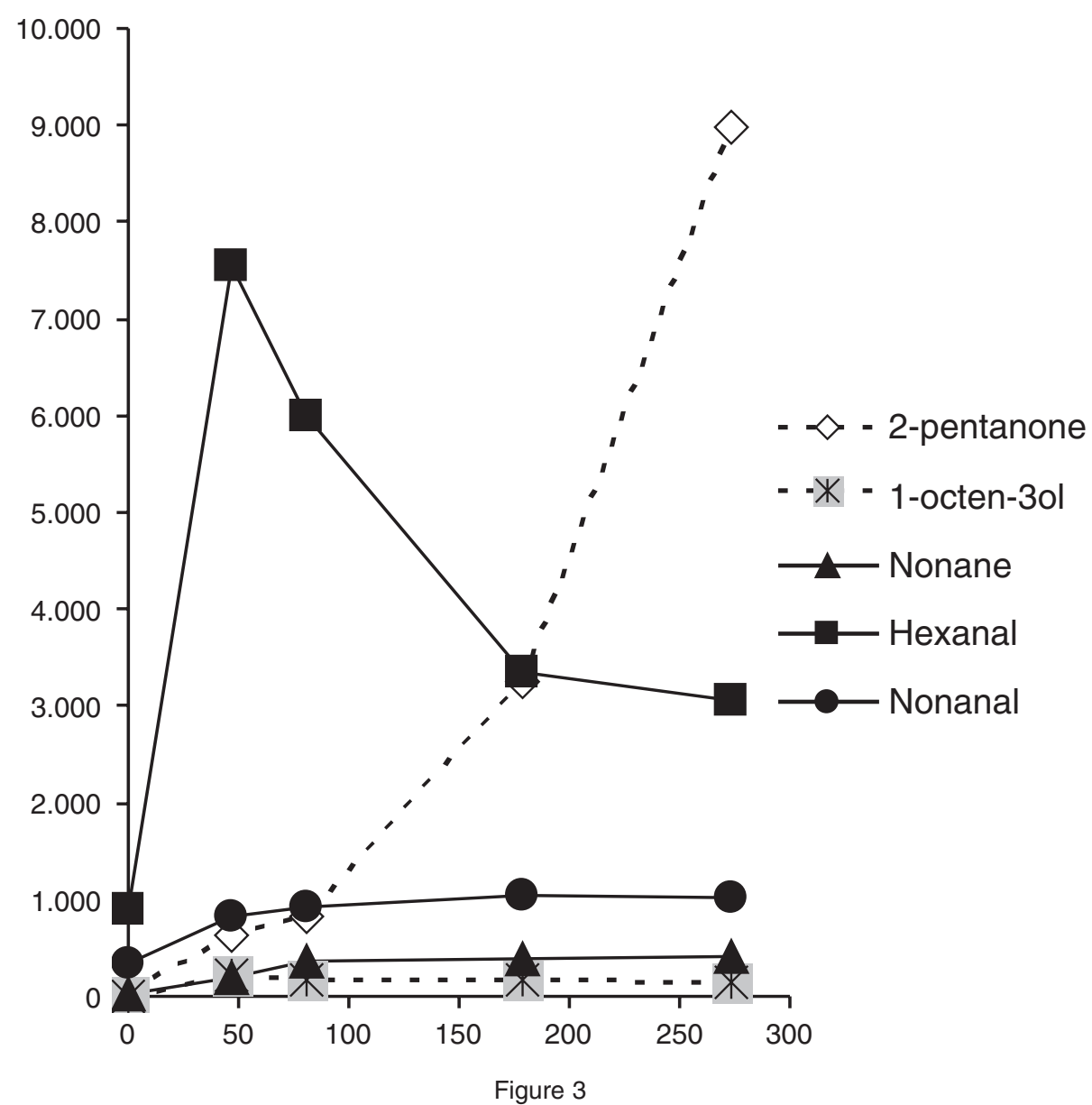

Changes in the amount of representative volatiles arising from lipid oxidation during Bayonne ham processing (As pg equivalent nonane/ $100 \mathrm{~g}$ ham).

intramuscular lipids which are both solvent and precursors of volatiles (Berdagué et al., 1993). Its depends also on processing traits such as the length and temperature (Buscailhon et al., 1993; Ruiz et al., 1999), the amount of salt (CoutronGambotti et al., 1999b) and the antioxidative pattern of the raw meat (Dirinck et al., 1997).

\section{LIPIDS AND SENSORY TRAITS OF DRY- CURED HAM}

\subsection{Triacylglycerol composition and physical properties of fat}

More than fatty acid composition, TAG composition determines the melting point and the solid fat content of both adipose tissues and inter and intramuscular fats, parameters strongly correlated with the consistency of fat. Thus each TAG possesses a melting point depending on its three fatty acids and on their distribution on the glycerol. Solid fat content at $20^{\circ} \mathrm{C}$ is strongly correlated with disaturated TAGs, mainly PSO $\left(R^{2}>0.90\right)$ because these TAGs are solid at ambient temperature (Davenel et al., 1999). On average, solid fat content of adipose tissue is around $20 \%$ with a large variation (from 7 to $30 \%$ ). Fat with a solid fat content at $20{ }^{\circ} \mathrm{C}$ lower than $15-17 \%$ lacks of consistency (Davenel et al., 1999). Because of the low amount of PSO and the high amount of $\mathrm{OOO}$, fat of lberian pigs presents the low solid fat content at ambient temperature (10$12 \%$ ) (Gandemer et al., 2000). This lack of consistency of fat affects some quality trait of drycured hams. The main traits associate with low fat consistency is the oily appearance and a poor cohesiveness of cuts (Ventanas et al., 2007). When hams are hanged, fat can drip. This trait is strongly associated with the positive image of Iberian drycured hams.

\subsection{Intramuscular lipids and dry-cured ham quality}

Intramuscular lipid content affects several quality traits of dry-cured hams. The first one is the aspect of slices because intramuscular lipids become visible when their content in muscles exceeds $5 \%$ (Buscailhon and Monin, 1994b). The hams with high intramuscular lipid content such as muscles from Iberian and Corsican pigs have a higher marbling score than those of Parma and Bayonne Hams (Rousset and Martin, 1998). Intramuscular lipids strongly affect color of ham slices. Thus, redness and brightness scores of ham cut decrease as intramuscular lipid content increases (Gou et al., 
1995; Ventanas et al., 2007). Hams with high intramuscular lipid content are oilier. Intramuscular fat also affects texture of hams. Thus, high intramuscular lipid content has a positive impact on ham tenderness and juiciness (Ventanas et al., 2007). Hams produced from genotypes with high intramuscular lipid content have more intense and persistent aroma (Hinrischen and Pedersen, 1995, Ventanas et al., 2007) because intramuscular TAGs are a good trap for most aroma compounds (Shahidi et al., 1986). High intramuscular lipid content associated with a long ripening process gives liable for a higher rancid flavor (Ventanas et al., 2007)

\subsection{Aroma arising from lipid oxidation and flavor of dry-cured ham}

Lipids play a key role in the overall aroma of drycured hams because of the volatiles generated through oxidation. The overall aroma of hams depends on the equilibrium between volatiles arising from lipid oxidation and those arising from amino acid and carbohydrate degradation reactions. Many studies have tried to establish relationships between aroma traits of dry-cured hams described by panelists and volatile compounds extracted from the same hams. These studies lead to some consistent conclusions. Thus, dry cured hams produced through a long ripening process have the highest aroma intensity because they have the highest amounts of all kind of volatiles generated through both lipid and amino acid degradation (Ruiz et al., 1999). During ripening, the aroma of dry-cured ham changes from fat, pork, fresh meat aroma notes to dry-cured and aged aroma notes (Buscailhon et al., 1994e; Dirinck et al., 1997; Flores et al., 1997; Ruiz et al., 1999). During the first steps of processing, volatiles mainly arise from lipid oxidation while those formed during the second part of ripening stage are formed from both lipid and amino acid degradation (Hinrischen and Pedersen, 1995). Rancid aroma is correlated to oxidation products, mainly to aldehydes such as nonanal and 2-hexenal which exhibit a strong rancid odor (Berdagué et al., 1993; Ruiz et al., 1999). Positive aroma notes such as "cured ham", "drycured ham" or "aged" aroma notes have been correlated to either branched aldehydes arising from amino acid degradation or methylketones arising from lipid oxidation (Buscailhon et al., 1994e; Flores et al., 1997; Hinrischen and Pedersen, 1995). All these results are consistent with the differences between the hams from different European countries (Figure 4). Thus, hams with a short processing (9-12 months) such as Bayonne and Parma hams show an aroma described as fresh meat and fresh fat aroma. In contrast, hams with a long ripening process (18-24 months) such as Corsican and Iberian hams have a more pronounced aroma with strong "rancid" and "cured" "mushroom" aroma notes (Figure 4) (Rousset and Martin, 1998). Aroma of Parma hams differs from that of other hams because of the high ester content in volatile fraction which have a pleasant fruity aroma (Barbieri et al., 1992; Careri et al., 1993).

\section{CONCLUSION}

Lipids are largely involved in the quality of drycured hams. Lipid traits of raw material strongly related to rearing conditions are content and consistency of lipids of both adipose and intermuscular fat. These traits influence aspects of cuts such as marbling, oily aspect and color.

During processing, lipids undergo lipolysis and oxidation. Lipolysis affects the structure of lipids but its implication in quality traits of final products remains largely unknown. In contrast, oxidation of fatty acids generates a large amount of volatile compounds. These volatiles play a key role in
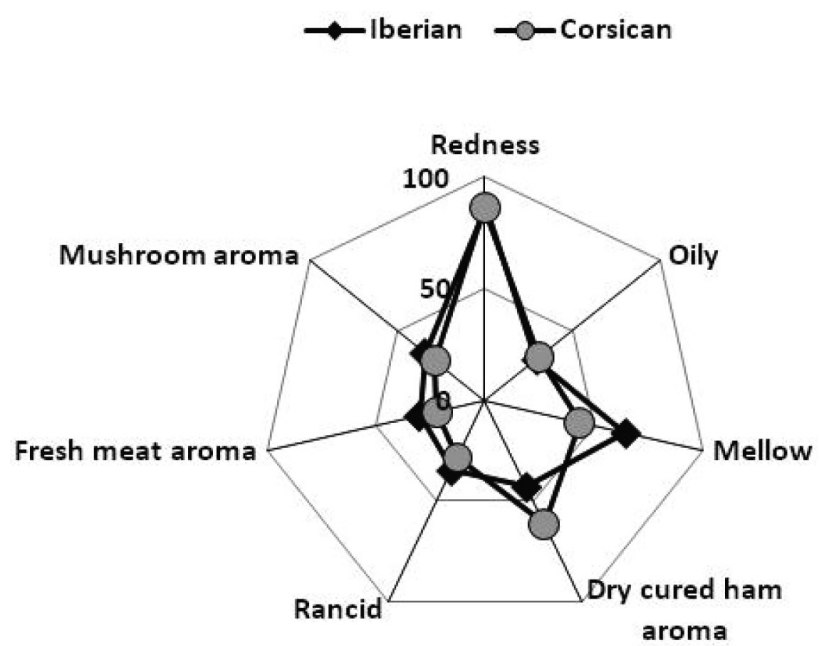
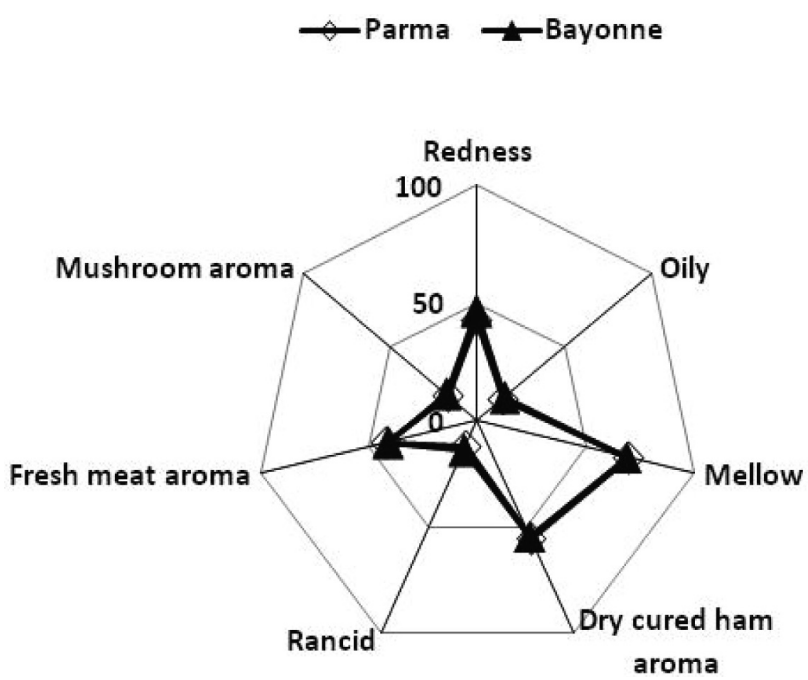

Figure 4

Comparison of sensory profiles of European hams. 
aroma of dry-cured hams. They contribute to various aroma notes. Aldehydes are responsible of rancid, fruity, and green aroma while methylketones have a more positive impact on ham aroma (aged and dry-cured ham odors).

Many papers have been devoted to describe the traits of raw material and the changes in meat and adipose tissues during processing. The quality traits of the final products result in complex interactions between characteristics of raw material such as lipid traits, enzyme equipment of the tissues and the control of the processes involved in chemical and physical changes affecting meat compounds during processing. Further studies are required for a better control of dry-cured ham processing while ensuring the taste and aroma typicity of the different types of dry-cured hams produced in European countries.

\section{REFERENCES}

Alasnier C, David-Briand E, Gandemer G. 1999. Lipolysis in muscles during refrigerated storage as related to metabolic type of the fibres in the Rabbit. Meat Sci. 52, 127-134.

Alasnier C, Gandemer G. 2000. Activities of phospholipases A and lysophospholipases in glycolytic and oxidative skeletal muscles in the rabbit. J. Sci. Food Agric. 80, 698-702.

Andrés Al, Cava R, Mayoral Al, Tejeda JF, Morcuende D, Ruiz J. 2001. Oxidative stability and fatty acid composition of pig muscle as affected by rearing system crossbreeding and metabolic type of muscle fibre. Meat Sci. 59, 39-97.

Andrés Al, Cava R, Ventanas J, Thovar V, Ruiz J. 2001. Sensory characteristics of Iberian ham: Influence of salt content and processing conditions. Meat Sci. 68, 45-51.

Antequera T, López-Bote CJ, Cordoba JJ, García C, Ascensio MA, Ventanas J, García-Regueiro JA, Díaz I. 1992. Lipid oxidative changes in the processing of Iberian pig hams. Food Chem. 45, 105-110.

Barbieri G, Bolzoni L, Parolari G, Virgili R, Buttini R, Careri M, Mangia A. 1992. Flavor compounds of drycured ham. J. Agric. Food Chem. 40, 2389-2394.

Belfrage P, Frederikson G, Strälfors P, Tornqvist H. 1984. Adipose tissue lipases, in B. Borgström, and H. L. Brockerman (Eds.) Lipases. Elsevier, Amsterdam, pp. 365-416.

Benito J, Vázquez C, Menaya C, Ferrera JL, García Casco JM, Silio L, Rodriganez J, Rodríguez MC. 2000. Evaluation of the productive parameters in different strains of Iberian pig, in CIHEAM (Ed) Tradition and innovation in Mediterranean pig production, Serie A, No 41. Zaragoza, pp. 113-121.

Berdagué JL, Bonnaud N, Rousset S, Touraille C. 1993. Influence of pig crossbreed on the composition volatile compound content and flavour of dry cured ham. Meat Sci. 34, 119-129.

Bolzoni L, Barbieri G, Virgili R. 1996. Changes in volatile compounds of Parma ham during maturation. Meat Sci. 45, 301-310.

Bosi P, Cacciavillani JA, Casini L, Lo Fiego DP, Marchetti M, Mattuzzi S. 2000. Effects of dietary high-oleic acid sunflower oil, copper and vitamin $E$ levels on the fatty acid composition and the quality of dry cured Parma ham. Meat Sci. 54, 119-126.
Buscailhon S, Monin G. 1994a. Déterminisme des qualités sensorielles du jambon sec. Viandes Prod. Carnés. 15 (1) 23-34.

Buscailhon S., Monin G. 1994b. Déterminisme des qualités sensorielles du jambon sec. Influence de la qualité de la matière première sur la qualité du jambon. Viandes Prod. Carnés. 15 (2) 39-48.

Buscailhon S, Gandemer G, Monin G. 1994c. Timerelated changes in intramuscular lipids of French Dry cured ham. Meat Sci. 37, 245-255.

Buscailhon S, Berdagué JL, Gandemer G, Touraille C, Monin G. 1994d. Effects of initial pH on compositional changes and sensory traits of French dry-cured hams. J. Muscle Foods. 5, 257-270.

Buscailhon S, Berdagué JL, Bousset J, Cornet $M$, Gandemer G, Touraille C, Monin G. 1994e. Relations between compositional traits and sensory qualities of French dry-cured ham. Meat Sci. 37, 229-243.

Buscailhon S, Berdagué JL, Monin G. 1993. Time-related changes in volatile compounds of lean tissue during processing of French dry-cured ham. J. Sci. Food Agric. 63, 69-75.

Careri M, Mangia A, Barbieri G, Bolzoni L, Virgili R, Parolari G. 1993. Sensory property relationships to chemical data of italian-type dry-cured ham. J. Food Sci. 58, 968-972.

Cava R, Ruiz J, Ventanas J, Antequera T. (1999). Oxidative and lipolytic changes during ripening of Iberian hams as affected by feeding regime: extensive feeding and alpha-tocopheryl acetate supplementation. Meat Sci. 52, 165-172.

Coutron-Gambotti C, Gandemer G, Casabianca F. 1998. Effects of substituting a concentrated diet for chestnuts on the lipid traits of muscle and adipose tissues in Corsican and Corsican $x$ Large White pigs reared in a sylvo-pastoral system in Corsica. Meat Sci. 50, 163-174.

Coutron-Gambotti C, Casabianca F, de Sainte Marie C, Gandemer G. 1999a. Quelles références produire pour définir un produit typique ? Le jambon sec dans les enjeux de développement de la filière extensive en Corse. Cahiers Agric. 8 (5) 363-371.

Coutron-Gambotti C, Gandemer G. 1999b. Lipolysis and oxidation in subcutaneous adipose tissue during drycured ham processing. Food Chem. 64, 95-101.

Coutron-Gambotti C, Gandemer G, Rousset S, Maestrini O, Casabianca F. 1999c. Reducing salt content of drycured ham: effect on lipid composition and sensory attributes. Food Chem. 64, 13-19.

Davenel A, Riaublanc A, Marchal P, Gandemer G. 1999. Quality of pig adipose tissue: relationship between solid fat content and lipid composition. Meat Sci. 51, 73-79.

Dirinck P, Van Opstaele F, Vandendriessche F. 1997. Flavour differences between northern and southern European cured hams. Food Chem. 59, 511-521.

Flores M, Alasnier C, Aristoy MC, Navarro JL, Gandemer G, Toldrá F. 1996. Activity of aminopeptidase and lipolytic enzymes in five sketetal muscles with various oxidative patterns. J. Sci. Food Agric. 70, 127-130.

Flores M, Grimm CC, Toldrá F, Spanier AM. 1997. Correlations of sensory and volatile compounds of Spanish Serrano dry-cured ham as a function of two processing times. J. Agric. Food Chem. 45, 21782186.

Frankel EN. 1982. Volatile lipid oxidation products. Prog. Lipid Res. 22, 1-33.

Frankel EN. 1985. Chemistry of autoxidation: Mechanism, products and flavor significance, in Min DB and 
Smouse T (Eds.) Flavor chemistry of fats and oils, : American Oil Chemist Society Press., Champaign, Illinois, pp. 1-37.

Gandemer G, Viau M, Caritez JC, Legault C. 1992. Lipid composition of adipose tissue and muscles with an increasing proportion of Meishan genes. Meat Sci. 32, 105-121.

Gandemer G. 1997. Phospholipides, lipolyse, oxydation et flaveur des produits carnés. OCL. 4, 1-7.

Gandemer G. 1999. Lipids and meat quality: lipolysis, oxidation, maillard reaction and flavour. Sci. Aliments. 19, 439-458.

Gandemer G, Viau M, Navarro JL, Sabio E, Monin G. 2000. Lipides et qualité des jambons secs méditerranéens, in CIHEAM (Ed.) Tradition and innovation in Mediterranean pig production, Serie A, 41, Sargoza, pp. 181-189).

Gandemer G. 2002. Lipids in muscles and adipose tissues, changes during processing and sensory properties of meat products. Meat Sci. 62, 309-321.

García C, Berdagué JL, Antequera T, López-Bote C, Córdoba JJ, Ventanas J. 1991. Volatile components of dry cured Iberian ham. Food Chem. 1, 23-32.

Girard JP, Bout J, Salort D. 1988a. Lipides et qualités des tissus adipeux et musculaires de porc. Facteurs de variations. 1ère Partie: lipides et qualités des tissus adipeux. Journées Rech Porcine en France. 20, 272278.

Girard JP, Bout J, Salort D. 1988b. Lipides et qualités des tissus et musculaires de porc. Facteurs de variations. 1ère Partie: lipides et qualités du tissu musculaire. Journées Rech Porcine en France. 20, 255-272.

Gou P, Guerrero L, Arnau J. 1995. Sex and crossbreed effects on the characteristics of dry-cured ham. Meat Sci. 40, 21-31.

Grosch W. 1987. Reactions of hydroperoxide products of low molecular weight, in Chan HWS (Ed.) Autoxidation of unsaturated lipids, Academic press, London, UK, pp. 95-139.

Hernández P, Navarro JL, Toldrá F. 1998. Lipid composition and lipolytic enzyme activities in porcine skeletal muscles with different oxidative pattern. Meat Sci. 49, 1-10.

Hernández P, Navarro JL, Toldrá F. 1999. Lipolytic and oxidative changes in two Spanish pork loin products: dry-cured loin and pickled-cured loin. Meat Sci. 51, 123-128.

Hinrischen LL, Pedersen SB. 1995. Relationship among flavor, volatile compounds, chemical changes, and microflora in Italian-type dry-cured ham during processing. J. Agric. Food Chem. 43, 2932-2940.

Leseigneur-Meynier A, Gandemer G. 1991. Lipid composition of pork muscles in relation to the metabolic type of the fibres. Meat Sci. 29, 229-241.

López-Bote CJ. 1998. Sustained utilization of the Iberian pig breed. Meat Sci. 49, S17-S27.

Martín L, Córdoba JJ, Ventanas J, Antequera T. 1999. Changes in intramuscular lipids during ripening of Iberian dry cured ham. Meat Sci. 51, 129-134.

Morrissey PA, Sheehy PJA, Galvin K, Kerry JP, Buckley DJ. 1998. Lipid stability in meat and meat products. Meat Sci. 49, S73-S86.

Motilva MJ, Toldrá F, Aristoy MC, Flores J. 1993a. Subcutaneous adipose tissue lipolysis in the processing of dry-cured ham. J. Food Biochem. 16, 323-335.

Motilva MJ, Toldrá F, Nieto P, Flores J. 1993a. Muscle lipolysis phenomena in the processing of dry-cured ham. Food Chem. 48, 121-125.
Motilva MJ, Toldrá F, Flores J. 1993b. Assay of lipase and esterase activities in fresh pork meat and dry-cured ham. Z Lebensm Unters Forch. 195, 446-450.

Motilva MJ, Toldrá F, Nadal MI, Flores J. 1994. Prefreezing hams affect lipolysis during dry-curing. $J$. Food Sci. 59, 303-305.

Narvaez-Rivas M, Vicario IM, Graciani Constente E, Léon-Camacho M, 2007. Changes in the concentration of free fatty acid, monoacylglycerol, and diacylglycerol in the subcutaneous fat of Iberian ham during dry-curing process. J. Agric. Food Chem. 55, 10953-10961.

Narvaez-Rivas M, Rios JJ, Arteaga JF, Quiliez JF, Barrero AF, Léon-Camacho $M, 2008 \mathrm{~b}$. Determination of entkaurene in subcutaneous fat of Iberian pigs by gas chromatography multi-stage mass spectrometry with the aim to differentiate between intensive and extensive fattening systems. Anal. Chim. Acta, 624, 107-112.

Narvaez-Rivas M, Vicario IM, Graciani Constente E, Léon-Camacho M, 2008b. Changes in the fatty acid and triacylglycerol profiles in the subcutaneous fat of Iberian ham during the dry-curing process. J. Agric. Food Chem. 56, 7131-7137.

Riaublanc A, Gandemer G, Gambotti C, Davenel A, Monin G. 1999. La détermination de la composition en triglycérides du tissu adipeux: un outil possible pour l'identification des jambons secs de haut de gamme. Journées Rech Porcine en France. 31, 301-307.

Rousset S, Martin JF. 1998. Caractéristiques sensorielles de jambons secs français, italiens, espagnols et classification de consommateurs suivant leurs préférences sensorielles. Proceeding - 7éme Journées des Sciences du muscle et technologies de la viande. Rodez, France.

Ruiz J, Ventanas J, Cava R, Andrés A, García C. 1999. Volatile compounds of dry-cured Iberian ham as affected by the length of the curing process. Meat Sci. 52, $19-27$.

Secondi F, Gandemer G, Luciani A, Santucci PM, Casabianca F. 1992. Evolution chez le porc corse, des lipides des tissus adipeux et musculaires au cours de la période d'engraissement traditionnelle sous châtaigneraie. Journées Rech. Porcine en France. 24, 77-84.

Shahidi F, Rubin LJ, D'Souza LA. 1986. Meat flavor volatiles: a review of the composition, technique of analysis and sensory evaluation. CRC Crit. Rev. Food Sci. Nutr. 24, 141-243.

Tejeda JF, Gandemer G, Antequera T, Viau M, García C. 2002. Lipid traits of muscles as related to genotype and fattening diet in Iberian pigs: total intramuscular lipids and triacylglycerols. Meat Sci. 60, 357-363.

Toldrá F., Flores M. 1998. The role of muscle proteases and lipases in flavor development during the processing of dry-cured ham. Critical Rev. Food Sci. 38, 331-352.

Toldrá F, Flores M, Aristoy MC, Virgili R, Parolari G. 1996. Pattern of muscle proteolytic and lipolytic enzymes from light and heavy pigs. J. Sci. Food Agric. 71, 124128.

Toldrá F, Flores M, Sanz Y. 1997. Dry-cured ham flavour: enzymatic generation and process influence. Food Chem. 59, 523-530.

Ventanas S, Ventanas J, Jurado A, Estévez M, 2006. Quality traits in muscles biceps femoris and back-fat from purebred Iberian and reciprocal Iberian x Duroc crossbred pigs. Meat Sci. 73, 651-659.

Ventanas S, Ventanas J, Tovar C, García C, Estévez M. 2007. Extensive feeding versus oleic and tocopherol 
enriched mixed diets for the production of Iberian drycured hams: effect on chemical composition, oxidative status and sensory traits. Meat Sci. 77, 246-256.

Viera-Alcaide I, Vicario IM, Escudero-Gilette ML, Graciani Constente E., Léon-Camacho M. 2007. A multivariate study of the triacylglycerols composition of the subcutaneous adipose tissue of Iberian pig in relation to the fattening diet and genotype. Grasas y Aceites. 59, 327-336.

Viera-Alcaide I, Vicario IM, Graciani Constente E., LéonCamacho M. 2007. Authentication of fattening diet of Iberian pig according to their triacylglycerol profile from subcutaneous fat. Anal. Chim. Acta. 596, 319-324.
Waite M. 1987. Handbook of Lipid Research 5: The phospholipases. New York: Plenum Press.

Whittington FM, Prescott NJ, Wood JD, Enser M. 1986. The effect of dietary linoleic acid on the firmness of backfat in pigs of $85 \mathrm{~kg}$ live weight. J. Sci. Food Agric. 37, 753-761.

Wilson BR, Pearson AM, Shortland FB. 1976. Effect of total lipids and phospholipids on warmed-over-flavor in red and white muscle from several species as measured by thiobarbituric acic analysis. J. Agric. Food Chem. 24, 7-10.

Recibido: $26 / 12 / 08$ Aceptado: 5/2/09 